\title{
100 YEARS OF A GENERAL PRACTICE: THE HISTORY OF THE DALTON SQUARE PRACTICE, LANCASTER 1903-2003
}

\author{
John H Chippendale, Partner 1963-1992
}

This article is a shortened version of a 44-page Practice Centenary Booklet produced by the practice and sold in aid of two local charities.

\section{INTRODUCTION}

The practice was started in 1903 by Dr James Aitken, a 44year-old Glasgow University graduate. He had lived in Dalton Square for a number of years and was Public Vaccinator and Medical Officer to the workhouse. The workhouse was on Quernmore Road to the east of the city. In later years it became the Bay View Hospital and then part of the Lancaster Royal Grammar School site. Dr Aitken's first surgery was in rented rooms in Stonewell House at the northern end of Great John Street. In the 1920s he took in Drs Millar and Howat, also Glasgow graduates, and in 1929 the three doctors moved to 8 Dalton Square. The practice has remained at this Georgian town house until the present day.

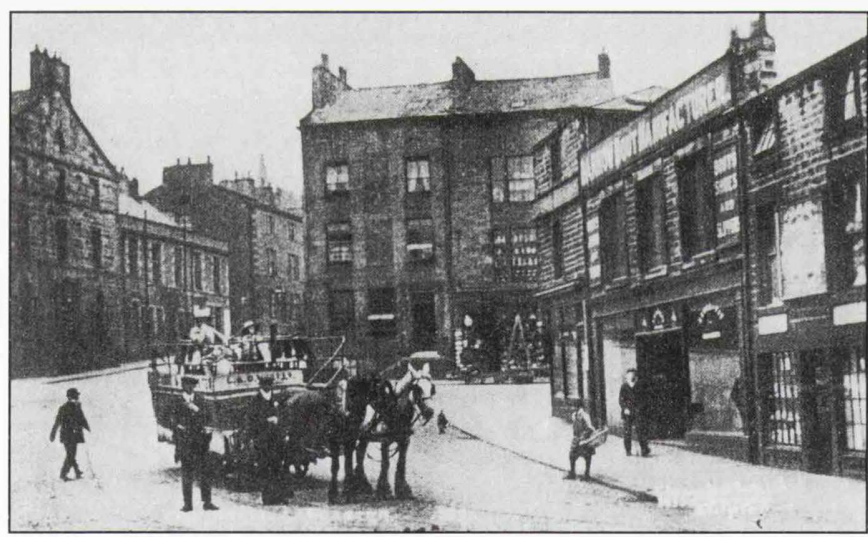

Lower St Nicholas Street at the turn of the nineteenth century. Stonewell House is in the centre, behind the horse-drawn tram.

(Image from 'Lancaster in old picture postcards', Stephen H Penney, European Library, 1983).

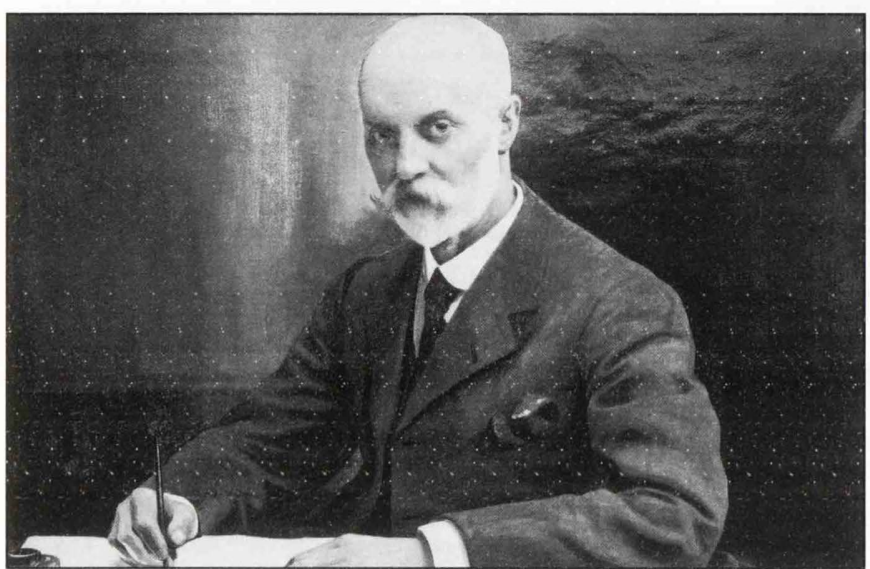

James Aitken, founder of the practice
The interior has been greatly modified over the years Initially the doctors used five rooms at the front of the house, now every inch of available space is used including the loft. In 1991 and 1998 there was a phased expansion into the alleyway to the north of the building giving the long narrow building much-needed width. The single-handed practice of 1903 has become an eight-partner practice in 2003, including two who job share.

During the preparation of the Centenary Booklet the practice was fortunate in tracing a former patient, now aged 90, who had worked for Dr Aitken. She described him as 'of small stature and a busy sort of man - his hands were very active when he talked'. Very useful also were the 1975 oral history interviews of Lancaster historian Elizabeth Roberts. She recorded quotes from two elderly patients about Dr Aitken and his style of practice.

\section{Mrs H (born 1903) \\ ER - "Did you all wear shoes or clogs for school?" \\ Mrs H - "I wore shoes. I couldn't wear clogs but the others wore clogs. I couldn't wear them. I always had sore feet and I was hardly at school, but the others wore them. The doctor was old Dr Aitken and he never sent her a bill in for me. "The poor wee lassie" he used to say. He was right Scotch. But he was a grand old doctor. He didn't send in a lot of bills, I can tell you'. \\ Mrs M (born 1917) \\ "Anyway m'dad was saying why his kids hadn't got these sore throats and old Dr Aitken just looked up and there was an old clothes rack, as they used to have in those days. Hanging from the rack was a big bunch of onions. Dr Aitken said "How long have you had that up there? Now that is where your disease is going. Take them down and try one." He took them down and there wasn't a sound onion. All rotten. Dr Aitken said that they had got the disease that was going about instead of the children."}

References to Dr Aitken in oral history interviews carried out in 1975 by Elizabeth Roberts, Lancaster University

Although he had started a new practice Dr Aitken, it seems, was quickly accepted by the older well-established practices in Lancaster. There was a need for further practices as the population of Lancaster had gone up from 25,000 in 1881 to over 40,000 in $190 \mathrm{l}^{(1)}$. Dr Aitken was president of the Lancaster Medical Book Club from 1913 to 1919. During the 1914-18 war he organised cover for local doctors on active service, and donated an ambulance for use at the front. This ambulance was affectionately known as 'Lancaster Lass'. In 1909 Dr Aitken would begin to use the Lloyd George envelopes for medical records. Envelopes of this type have only just been relegated to storage in the surgery cellar as all records are now made on the computer. The Lloyd George Act introduced the insurance principle into healthcare, with workers and employers paying for a 'stamp' week by week. The payment of doctor's bills for the worker was now made easier, but not those of his family. However, as Dr Roberts 
shows above, Dr Aitken was easy-going about families paying his bills.

Dr Aitken practised until the late 1920s when he married late in life and retired to a house he had had built in Scotforth, a suburb on the south side of Lancaster. He died in 1933, curiously a few months before I was born. There is a fine memorial headstone in Scotforth Cemetery and the Lancaster Guardian carried a lengthy tribute to him.

\section{THE PRACTICE STORY - DECADE BY DECADE}

\section{$1903-1913$}

These were the years of $\mathrm{Dr}$ Aitken working alone and building up the practice from the rooms in Stonewell House. He continued to be Public Vaccinator and Medical Officer at the workhouse where there were 350 inmates. He is said to have done late evening ward rounds by candlelight. He did house calls by pony and trap and never used the new-fangled telephone.

\section{3-1923}

The First World War dominated this decade. Although too old to serve Dr Aitken was much concerned with helping the war effort, as already mentioned. In 1922 he was a patron of a Grand Bazaar held in the Ashton Hall to raise funds for the relatively new Royal Lancaster Infirmary.

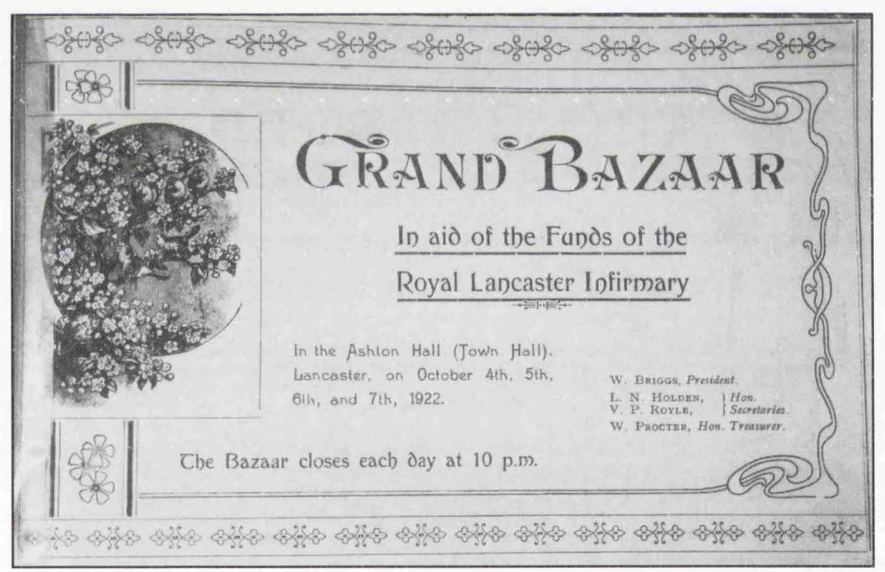

1922 Infirmary Grand Bazaar programme

At the end of this decade he took in the two young doctors, Archibald Millar and Robert G Howat. It is said he called them his nephews to ease their acceptance into Lancaster medical society, but they were unrelated. Dr Millar was a 'son of the manse' from New Cumnock in Ayrshire and Dr Howat had been a pharmaceutical chemist in Glasgow before taking up medicine.

\section{3-1933}

There were no great medico-political changes in this decade, in which Dr Aitken retired and died. Giles Howson joined the practice and Archie Millar became increasingly incapacitated by pulmonary tuberculosis. The expanding practice was finding the rooms at Stonewell rather crowded and in 1929 the practice moved to No 8 Dalton Square.

Giles Howson was the first Englishman to join the practice. He was a local man who was educated at Lancaster Royal Grammar School and Manchester University Medical School. A Quaker, he had been an orderly on ambulance trains during the 1914-18 war. He is remembered as a skilful obstetrician in those days of home confinements. His son George, who qualified in law and became coroner for northwest Lancashire, remembers that the demands of the practice on his father at this time were very great.

Robert Gold Howat was now well established in Lancaster and needs his full name here to distinguish him from his son Robert James Howat, who succeeded him in the practice. Robert $\mathrm{G}$ was a man of great Scottish charm with a puckish sense of humour. With his pharmaceutical background he was noted for making up a good bottle of medicine. The practice was dispensing and employed a dispenser who worked from a small area between the two downstairs surgeries and the waiting room. Robert $\mathrm{G}$ played his violin in the infirmary wards at Christmas and my wife and I had the pleasure of attending a musical evening at his home when, after dinner, Dr Howat and a friend on piano played duets. This was in the early 1960s.

Archie Millar was a bachelor and when he died in his early fifties the city lost a much-loved physician. He is remembered to this day by Miss Nancy Leighton, formerly almoner at the infirmary, as 'a very nice man and very well liked'. He is also remembered in notes left by Leonard Mather, a Lancaster GP from 1924 to 1949 , as being good to the poor: "he was a friend to them all, be they the Lord's poor, the Devil's poor or just the poor devils'. Dr Mather's notes can found in the minutes of the Lancaster Medical Book Club ${ }^{(2)}$

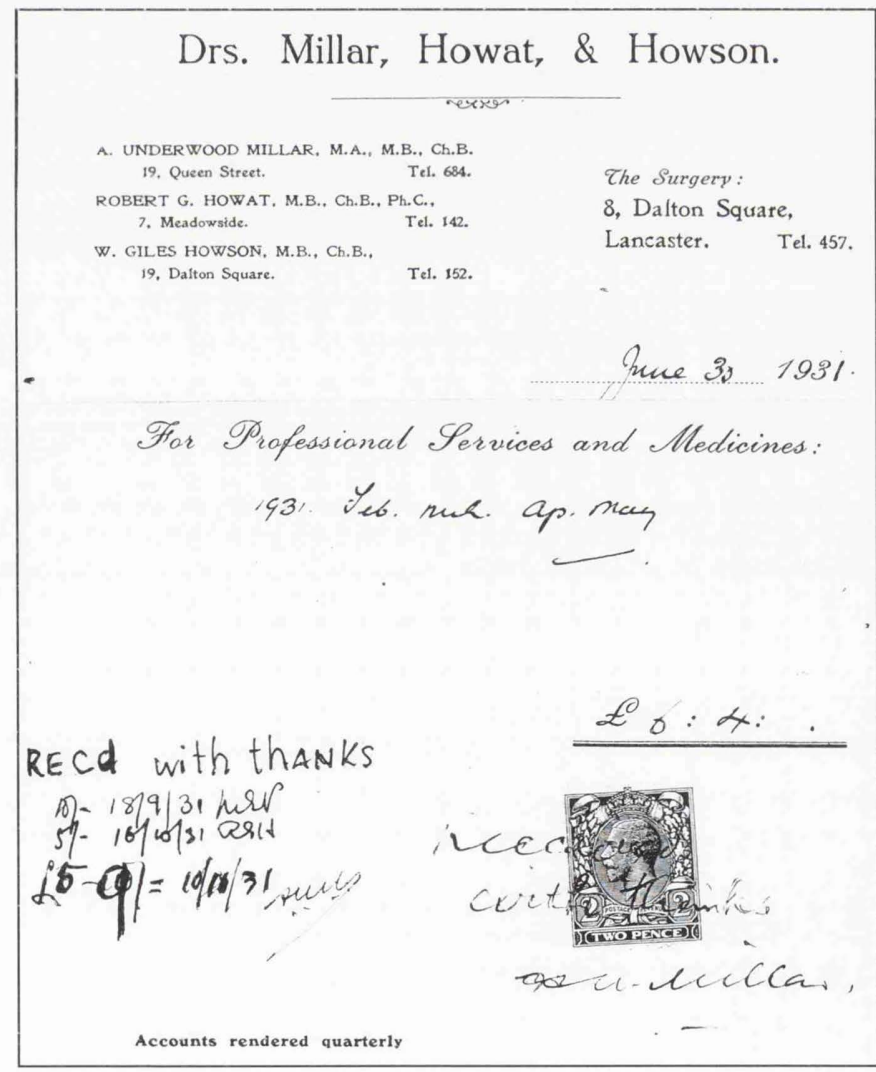

Payment was often by instalment

\section{3-1943}

This was the decade of what might be called the practice's great triumvirate, Drs Howat, Howson and Stewart. James Stewart had joined the practice in 1933 when Archie Millar retired. Another Glasgow graduate, he had taken up medicine late after serving in the 1914-18 war and working for some time as an accountant.

As throughout the previous decade there were no great changes in the running and financing of the practice. Bills 
were sent out and the caretaker's husband did rounds collecting monies due. Payment was often by instalments.

The three doctors were honorary physicians at the infirmary, with Dr Stewart having a special interest in the physiotherapy department. In their work the doctors were very 'hands on', conducting home confinements, giving dental anaesthetics and treating their patients in hospital. Effective drugs were now available and Dr Stewart used the sulphonamides in treating pneumonia and, innovatively, for impregnating dressings. He found ulcers and wounds healed more rapidly if a small electrical current was passed through the dressing. His work in this field gained him the higher degree of MD Glasgow in 1942. Although we have no figures, we know that the three partners had built the practice up to a list of well over 10,000 patients and they needed the assistant help given by a retired former missionary doctor, Mary Andrews.

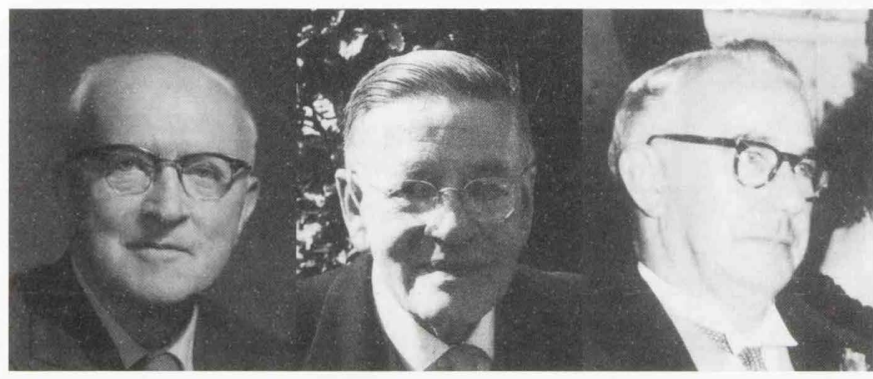

Drs RG Howat, Howson and Stewart

The partners were not called up for military service when the 1939-45 war started but they covered for absent general practitioner colleagues and cared for troops at Bowerham Barracks and at the large temporary army camp at Quernmore Park.

\section{3-1953}

This decade saw the end of the war and the start of the National Health Service. Tragedy has hit the practice hard over the century. Archie Millar's early death was the first tragedy and then in $1944 \mathrm{Dr}$ and Mrs Howat's eldest daughter, 24-year-old Margaret, was killed in a road accident in Rome when serving as a physiotherapist with an Army Rehabilitation Unit. Towards the end of the decade, the retirement of Giles Howson at the early age of 54 was also a tragedy in that so skilful a doctor could not complete a full working life.

Drs Howat, Howson and Stewart now became Drs Howat, Stewart, Hood, Anderson and Howat, with the second Dr

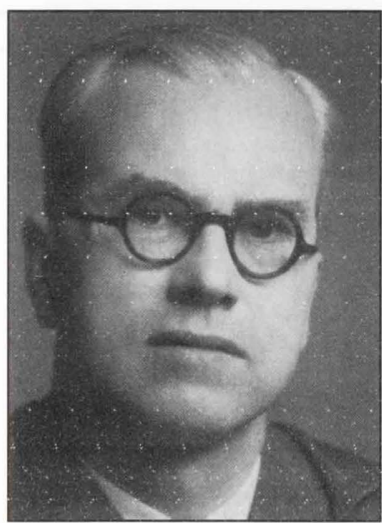

James Hood on his graduation
Howat being Robert James, the son of Robert Gold. James Hood joined in 1947 just before the NHS started and Graham Anderson came in 1948 to help during the illness of Dr Howson and became a partner in 1951. Drs Hood and Anderson had known each other as students in Glasgow and both had served in the RAF Medical Branch during the war. Robert James Howat had been a medical student at St Mary's Hospital in London during the war and after the war had served in the Royal Army Medical Corps in Palestine and Germany.
1948 was the year of great change. The old system of doctor's bills and membership of various insurance and friendly societies was out and funding from central government came in. General practitioners were paid on a capitation basis at $£ 1.00$ per head for each person registered with them. The practice had about 14,000 patients by this time but there was now a small staff and the many overheads of running a large practice. The government agreed compensation for the practice goodwill now lost but the money was held at a very low rate of interest until a partner retired.

Hospitals became centrally funded and consultants were appointed to take the places of the honorary physicians. A general practitioner no longer had an active role when his or her patients were in hospital. An exception was in the retention of GP Maternity units and some GP-run cottage hospitals. As will be seen, the Dalton Square partners took up hospital posts as clinical assistants.

\section{3-1963}

This was a decade which the firm almost completed without a need to change the headed notepaper but in $1962 \mathrm{I}$ joined the firm as an assistant, became a partner in 1963,and later took over Dr Stewart's list of patients. I came as an assistant to take the place of Leslie Atkinson who moved to be a singlehanded practitioner at Cartmel. As I became a partner, 'old' Dr Howat retired. He had progressively reduced his workload as his son became established.

As already hinted, the basic NHS pay was not good so the firm diversified by taking up many of the new clinical assistantship sessions offered by the NHS. These were mainly at the Moor Hospital. Drs Hood, Anderson and RJ Howat had a total of eight sessions working in psychogeriatrics, surgery, neurosurgery and orthopaedics. Graham Anderson also worked in the EEG department and would give basal sedation for neurosurgery and Dr Howat had an orthopaedic operating session with Mr ID Kitchin. Dr Hood was the Prison Medical Officer at Lancaster Castle and a DSS Examining Medical Officer. Dr Anderson was Medical Officer at the army training camp on Halton Road as well as helping Edward Byrne, the paediatric consultant, with cover at Beaumont Hospital. As in the busy war years the partners were in need of assistance, which came first from Dr Atkinson in 1958.

Dr RJ Howat found time to command 44 Field Ambulance TA and for this work he was awarded the OBE in 1961. Dr Hood had received the MBE for his RAF service in East Anglia, where many damaged bombers with injured crew members landed after raids over Germany.

\section{3-1973}

During this decade both Dr Stewart and Dr Hood retired, with Roger Lomax taking over Dr Hood's patients. In mentioning the 'taking over of patients' it should be pointed out that the practice operated a personal list system and still does to the present day.

Dr Lomax was born in Lancaster and was at Caius College Cambridge and the Westminster Hospital. Dr Hood retired at the age of 55 to become a Prison Medical Officer in the Bahamas. Dr Stewart, who was 65, retired to live close to his daughter in Hertfordshire. In 1964 I became the first Medical Officer at the newly created St Martin's College of Education and started doing DSS work. In the reshuffles due to the retirements, Dr Lomax became Prison Medical Officer and took over Dr Hood's hospital sessions. Dr RJ Howat, an old boy, became Medical Officer at Lancaster Royal Grammar School. 
A huge amount of work over and above the basic day to day care of the practice list was being carried out and this was mainly due to the poor level of the capitation fee. It was not surprising that there was unrest among GPs throughout the land and in 1966, ably led by the charismatic Dr Cameron, all GPs threatened to resign. Dr Hood famously spoke out at a local meeting to demand a three-fold increase in the capitation fee to solve all the problems of general practice at a stroke. In the end the Government agreed to the 'Doctors' Charter' in which remuneration was increased by $30 \%$ spread over two years. There were subsidies for rent and rates and for part of staff salaries. A GP's pay now came in three slices: an improved capitation fee, a mini salary known as a basic practice allowance and fees for items of service given such as inoculations and maternity care. The government offered money for GP merit awards but this offer was rejected by $85 \%$ of GPs and it was agreed to channel this money into seniority payments.

It may be of interest to record that during this decade many home confinements were conducted by the partners and the domiciliary midwives. It was decreed that if a first confinement in hospital had been normal the delivery of second, third and fourth babies could be at home. The practice had some 150 deliveries each year which fitted into this category

It is now sad to relate further tragedy affecting the Dalton Square practice 'family'. In 1968 Dr Melvyn Taylor joined the practice. He was a Newcastle graduate. In 1971, just three years into his partnership, he went on holiday to the Island of Bute with his wife, Elspeth, and two young sons. Here a most tragic event occurred as he died in a sailing accident. On the day Dr Taylor died Dr R J Howat had a major heart attack and was admitted to hospital. During this unhappy year Dr R G Howat died aged 81

During the decade the practice made the first expansion into the rear of the premises and created two new surgeries, a treatment room and a meeting room which could also be used as a flat for a locum tenens. Open surgeries ended in 1964 when the partners started an appointment system.

Brian Higton took over Dr Taylor's patients in 1972. He was a Manchester graduate with higher qualification in obstetrics and gynaecology.

\section{3-1983}

The practice became a training practice in 1973 with Dr Anderson as trainer. A graduate in medicine who wished to become a partner in general practice now had to undertake three years of vocational training. The two years in hospital had to include Accident and Emergency and obstetric work There then followed one year of general practice attachment. David Longden, who joined the practice in 1977 to become a sixth partner, was the first partner to have done the three

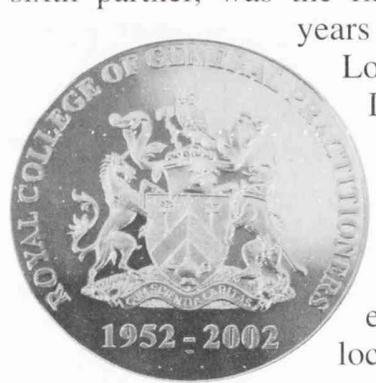

vocational training. David

Longden is from Manchester and is a Leeds University graduate.

Dr Howson died in 1973 at the age of 75 . He had not had the best of health during 20 years of retirement but had been able to enjoy his interests of researching ocal history and beekeeping.

The RCGP gold medal Drs Stewart, Anderson and RJ Howat had been foundation members of the

Royal College of General Practitioners and Dr Anderson went on to become a fellow and to receive the college's gold medal in 2002
He was interested in research into general practice and produced several papers on diuretic-induced diabetes. Dr Howat was involved in medical education by taking a medical student from Manchester for two weeks each half year. For many years Dr Howat was the representative of local GPs on the Local Medical Committee at Preston. This committee had a voice at meetings of the Executive Council, later re-named the Family Practitioner Committee, and put the GPs' point of view to the administrators and paymasters.

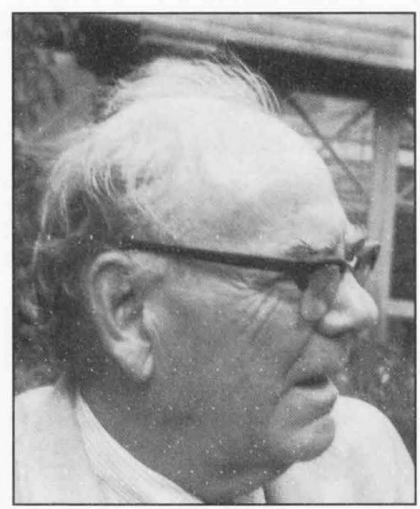

GH Anderson

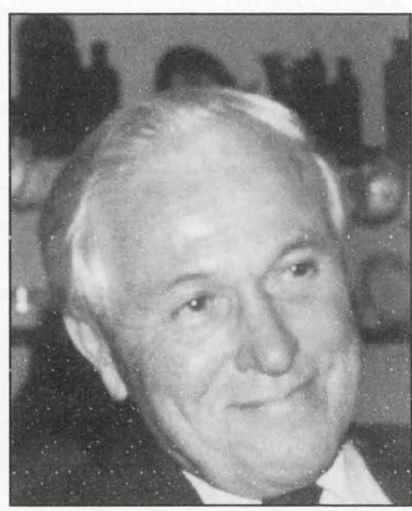

RJ Howat

\section{3-1993}

This decade began with the death of ex-partner Dr Stewart, aged 85. In 1960 he wrote an archaeological guide and glossary and he had continued his interest in archaeology in his retirement. There then followed a series of retirements and successions beginning with Dr Anderson retiring and being replaced by Andrew Paton in 1983. In 1987 Dr Howat retired and was replaced by Nigel Cook and at the end of the decade I retired to be replaced by Neal Vaughan-Jones. In 1985 the number of partners increased to seven with the appointment of Neil Eckersley. The team of Drs Howat, Chippendale, Lomax, Higton, Longden, Paton and Eckersley of 1985 was a far cry from Dr Aitken working on his own in 1903.

In 1990 the Government of the day introduced targets to be met before Item of Service claims were paid. A high percentage of uptake for childhood inoculations and cervical smears had to be shown to obtain this sector of pay. There were also payments for childhood screening examinations and preventative medicine clinics.

After some years of hoping that the partnership might expand into the other half of the semi - detached building, and nothing coming of these ambitions, the partners decided to build two extra surgeries over the alley to the north and to expand into the second floor of number 8. Two treatment rooms for the practice nurses were in the new plan. The major refurbishment was carried out without the building being closed.

\section{3-2003}

This decade began badly with the death after only six years of retirement of Dr Howat. Also, Dr Higton became aware of the illness which was to end his life so tragically in 1998 at the age of 56 and without a meaningful retirement. Margaret, his wife, died two weeks before him. She was aged only 54 and had had longterm illness. Dr Higton was replaced by Howard Fairhurst.

Gillian Pilling became a partner in 1993. She had worked for some years as an assistant to the practice. In 2000 she left to work full time at St John's Hospice and the practice appointed Anna Kalougin as an assistant.

Dr Lomax retired in 1994 and was replaced by Timothy Reynard, who brought computer expertise to the practice. 


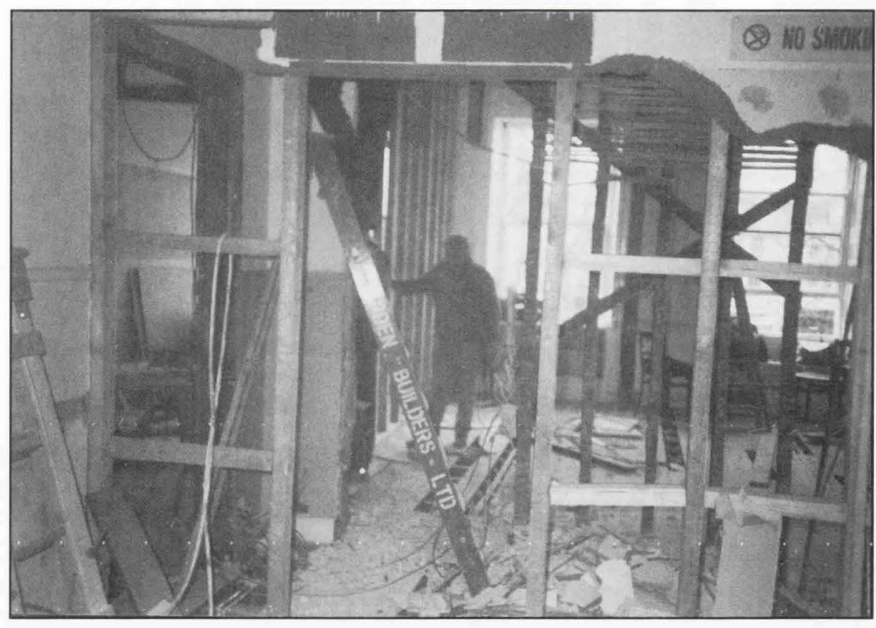

1991 Refurbishment without the building being closed

The administrative side had been computerised for some time but now each partner had a computer on their desk. In 1995 the partnership became fundholding and joined with three other Lancaster practices to form the Lancaster Multifund. Fundholding was concerned with 'buying' secondary care, ie operations, for patients from a notional sum of money allocated to the practice. Savings made could be ploughed back into the practice. Political change meant that fundholding lasted for only three years for the practice. At the end of this decade the practice opted for a Personal Medical Services (PMS) contract with the Morecambe Bay Primary Care Trust (MBPCT). This meant that the practice was paid by way of a PMS budget based on previous levels of payment and the paperwork of the old three-sector method of payment was reduced. Records of patient numbers and items of service given were still kept, to monitor the amount of the PMS budget.

Although they had already expanded once more by fashioning a doctor's office in the loft the partners, and the by now large staff, still needed more space and in 1998 two more surgeries were created under the arch and a large airy waiting room added on the north side. Patients now entered via a new door a short distance up the former alley. The much-needed width previously mentioned had now been achieved.

In 2001 Dr Vaughan-Jones and his wife, Kate Breckon, began to job share and in 2003, 100 years after the practice started, Juliet McGrattan was appointed as a salaried GP.

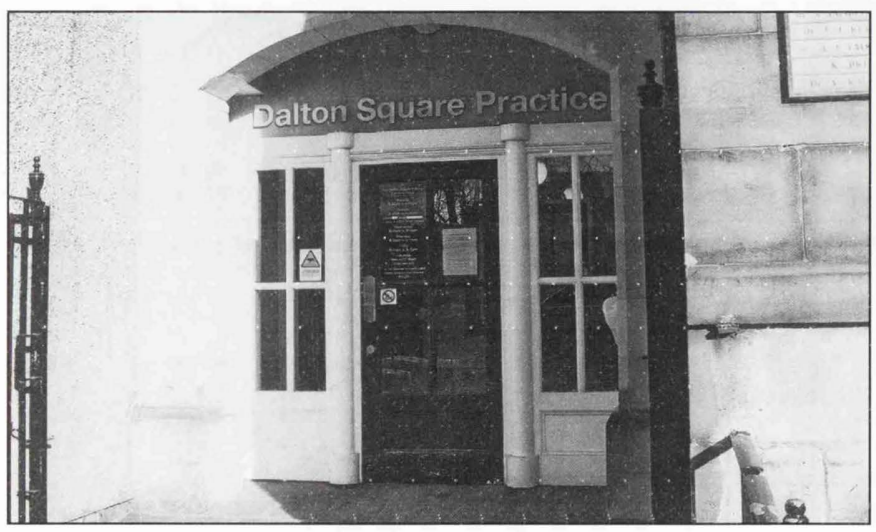

The new entrance to the surgery

\section{SOME FACTS AND FIGURES}

Some twenty-two doctors have worked as partners in the practice through the century. Of the forty-nine children of the practice only three have become doctors although there are now three in medical training. Two children have become veterinary surgeons.

From the small beginning in 1903 it seems the practice grew rapidly to the time of the start of the NHS when there were 14,000 patients, about a quarter of the population of the city and the surrounding $\operatorname{area}^{(3)}$. The present list size is 13,600 .

Dr RJ Howat and Brian Higton kept records in the 1980s and showed that the practice saw over 45,000 patients each year. One could play with figures and extrapolate that, in the last fifty years, there have been approximately two and a half million consultations at the Dalton Square Surgery.

In the winter of 1963 Robert J Howat and I and our families skated at Freeman's Wood on the Marsh and I had to leave at intervals to check whether any calls had to be done. There were no bleeps or mobile telephones at that time. Indeed it was not until the last decade that the on-call doctor could receive calls to a mobile telephone. In all the previous decades a spouse or caretaker took messages to pass on. The partners used deputising services in the last decade and were part of a co-operative scheme for weekend calls.

Until some way into the last decade the partners and assistants did all the on-call work of the practice. There was a responsibility for the patients 24 hours a day and 365 days a year. I kept records of my out of hours work during my last 10 years in the practice. In 1985, for example, I did 216 weekend calls, averaging 29 per weekend and 138 evening calls, averaging 3.6 per evening. There were 55 calls between $11.00 \mathrm{pm}$ and 7.00 am and 37 of these night calls caused me to get out of bed. This was working a 1 in 6 roster.

\section{THE SURGERY STAFF}

When Dr Aitken started the practice in the rented rooms in Stonewell House he had some help from his landlady but he made up medicines himself working from a large cupboard in the hall. From 1929, at Dalton Square, there was a dispenser and a caretaker, and later on a receptionist. From 1948, when the separate hospital service developed under the NHS, and there was a need for typed referral letters, a secretary was appointed. As all aspects of running the practice became more complicated the secretary became a practice manager. The present manager is Sandy Clark and her deputy is Leanne Thompson and they both took leading roles in organising the centenary celebrations.

A team of secretaries/receptionists was required to cover the 45,000 movements of patient records each year. In the last

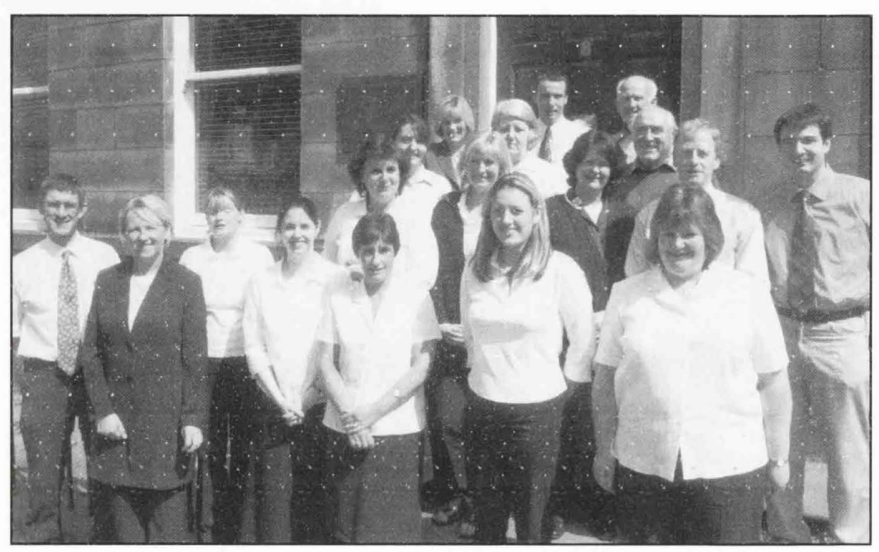

Partners (including two ex-partners) and staff 2003 (Photograph originally published in the Lancaster Guardian) 
decade the use of the computer to record consultations caused some staff redundancies but there is still a staff of 18 looking after the ten doctors. The partners and staff were photographed at the front of the surgery by the Lancaster Guardian at the beginning of the centenary celebrations.

For many years the practice worked closely with the district sisters, nurses, health visitors and midwives who were employed by the Local Authority. In 1989 the practice employed a nursing sister, with Janet Walker being the first. Now there is a team of four working from the two treatment rooms. Health visitors and other ancillary workers have remained attached.

\section{POSTSCRIPT}

The practice became known as 'The Dalton Square Practice' in 1993. From 1929 to 1993 it was known as 'The Surgery, 8 Dalton Square' and the heading of the practice notepaper changed as the members of the firm changed.
Acknowledgements: All the Dalton Square partners, and spouses and children of partners, past and present, who have given me material either anecdotally or formally; Sandy Clark, Leanne Thompson and all other staff at Dalton Square; Mr George Howson; Dr Elizabeth Roberts; Miss Nancy Leighton; Mrs Muriel Reay, Mr and Mrs David Reay; Mr John Sandham. All who helped in the production of the Centenary Booklet on which this article is based.

\section{REFERENCES}

1 A History of Lancaster 1193-1993. edited by Andrew White. Ryburn Publishing 1993

2 The Minutes of the Lancaster Medical Book Club. edited by GH Anderson. Carnegie Publishing 1997

3 Changes in a General Practice 1948 to 1987. GH Anderson, RJ Howat. Published privately 1987

\section{QUID EST HOC?}

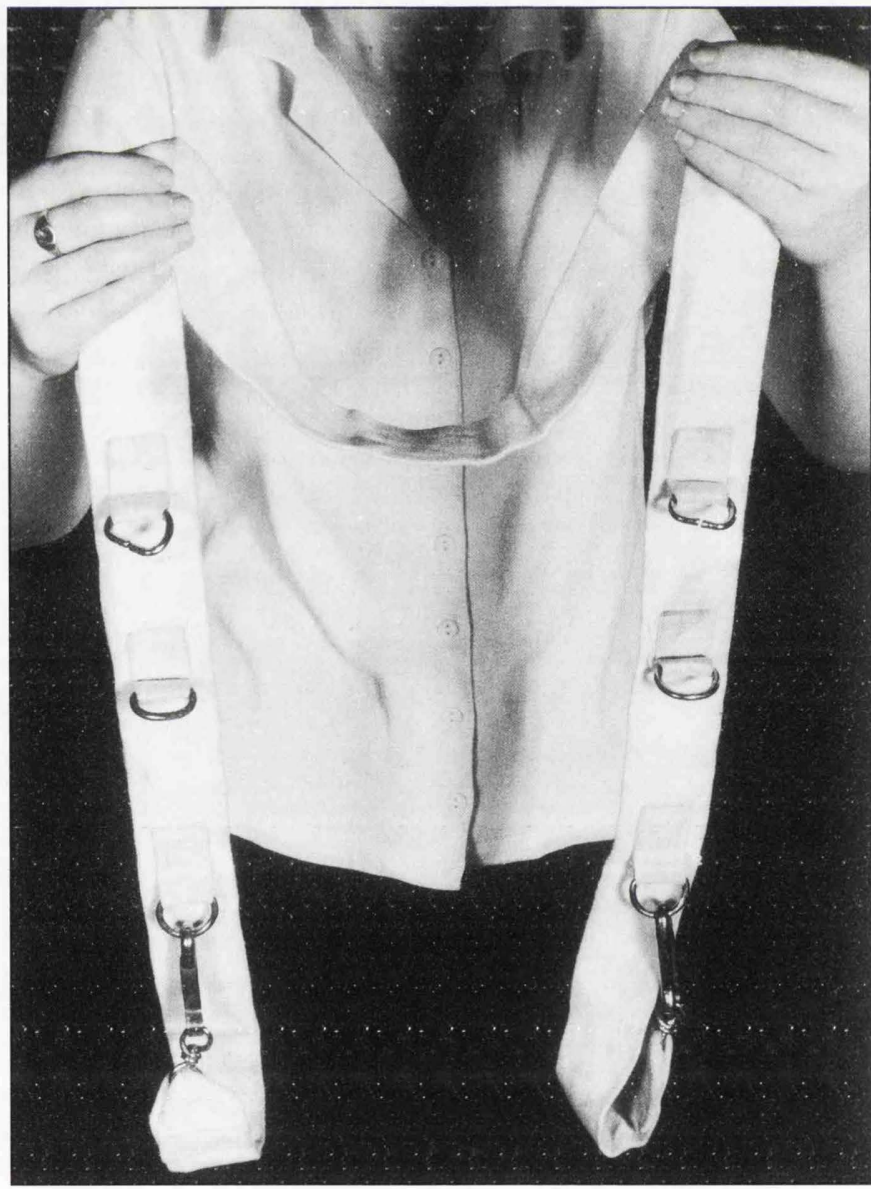

This object was found packed in a small brown canvas bag. What is its name and function?

Please send answers to the Editor, Morecambe Bay Medical Journal, Education Centre, RLI.
A $£ 25$ book token will be awarded for the first correct answer to be drawn at random. 